\title{
Soil organic carbon variation in relation to land use changes: the case of Birr watershed, upper Blue Nile River Basin, Ethiopia
}

\author{
Wondimagegn Amanuel ${ }^{1 *}$, Fantaw Yimer $^{2}$ and Erik Karltun ${ }^{3}$
}

\begin{abstract}
Background: This study investigated the variation of soil organic carbon in four land cover types: natural and mixed forest, cultivated land, Eucalyptus plantation and open bush land. The study was conducted in the Birr watershed of the upper Blue Nile ('Abbay') river basin.

Methods: The data was subjected to a two-way of ANOVA analysis using the general linear model (GLM) procedures of SAS. Pairwise comparison method was also used to assess the mean difference of the land uses and depth levels depending on soil properties. Total of 148 soil samples were collected from two depth layers: 0-10 and $10-20 \mathrm{~cm}$.

Results: The results showed that overall mean soil organic carbon stock was higher under natural and mixed forest land use compared with other land use types and at all depths (29.62 $\pm 1.95 \mathrm{Mg} \mathrm{C}^{-1}$ ), which was 36.14, 28.36, and $27.63 \%$ more than in cultivated land, open bush land, and Eucalyptus plantation, respectively. This could be due to greater inputs of vegetation and reduced decomposition of organic matter. On the other hand, the lowest soil organic carbon stock under cultivated land could be due to reduced inputs of organic matter and frequent tillage which encouraged oxidation of organic matter.

Conclusions: Hence, carbon concentrations and stocks under natural and mixed forest and Eucalyptus plantation were higher than other land use types suggesting that two management strategies for improving soil conditions in the watershed: to maintain and preserve the forest in order to maintain carbon storage in the future and to recover abandoned crop land and degraded lands by establishing tree plantations to avoid overharvesting in natural forests.
\end{abstract}

Keywords: Soil organic carbon, Soil properties, Land use change, Blue Nile Basin

\section{Background}

Land use changes in the tropics are responsible for 12$20 \%$ of the human-induced greenhouse gas emissions and are expected to remain the second largest source of greenhouse gas emission also for the future (van der Werf et al., 2009; IPCC 2007). The dominant type of land use change is the conversion of forest to agricultural systems with continuously high rates of 13 million

\footnotetext{
* Correspondence: wondimagegn.amanuel@yahoo.com;

wondem17@gmail.com

${ }^{1}$ Hawassa Environment and Forest Research Center (HEFRC), Hawassa, Ethiopia

Full list of author information is available at the end of the article
}

hectare being deforested per year (FAO 2005). Various studies have been conducted to assess the effect of land use changes on soil physical and chemical properties (Yimer et al. 2007; Lemenih et al. 2004; Singh et al. 1995). Yimer et al. (2007) compared crop lands, forest lands, and grazing lands and found that soil organic carbon decreased in crop lands as compared to forest lands. Another study conducted by Lemenih et al. (2004) showed that soils under Eucalyptus saligna Sm. deteriorated more than those in traditional farming. Singh et al. (1995) also showed that planting trees on alkaline soils increased organic carbon and reduced the soil $\mathrm{pH}$ more than in the open lands.

(c) The Author(s). 2018 Open Access This article is distributed under the terms of the Creative Commons Attribution 4.0 International License (http://creativecommons.org/licenses/by/4.0/), which permits unrestricted use, distribution, and reproduction in any medium, provided you give appropriate credit to the original author(s) and the source, provide a link to the Creative Commons license, and indicate if changes were made. The Creative Commons Public Domain Dedication waiver (http://creativecommons.org/publicdomain/zero/1.0/) applies to the data made available in this article, unless otherwise stated. 
Soil organic carbon inventories are characterized by large uncertainties that may result from: (i) the large spatial variability of soil properties (such as large grain size, bulk density, soil thickness, and SOC concentration) and resulting SOC stock (Don et al. 2011, 2007), (ii) the imperfect knowledge of the link between environmental conditions and SOC stocks, and (iii) the limitation of regional data sets (such as geological and soil maps) to represent the small variability of soil properties (Homann et al. 1995). This is especially true in mountain environments, which are characterized by a greater geo-diversity than any other landscape (Slaymaker et al. 2009; Korner 2003).

Factors that may be important for increasing SOC storage include (i) litter production (both above and below ground); (ii) litter quality; (iii) placing organic matter deeper in the soil either directly by increasing below-ground inputs or indirectly by enhancing surface mixing by soil organisms; (iv) increasing physical protection through either intra-aggregate or organic mineral complexes; and (v) microclimate change (Lemma et al. 2006). On the other hand, elevation and temperature differences are identified as the dominant controls on mountain SOC at regional scales (Djukic et al. 2010; Van Miegroet et al. 2007, 2005; Leifeld et al. 2005), local topographic changes (e.g., slope curvature and aspect, Egli et al. 2009; Tan et al. 2004), soil properties (e.g., soil type, soil moisture, pH and clay-content; Djukic et al. 2010; Leifeld et al. 2005), and vegetation (e.g., type and stand age; Luyssaert et al. 2008; Zhou et al. 2006) may introduce a large variability of mountain SOC at local scales. Small-scale variability may even impose strong scatter at large-scales and conceal relationships between SOC, topography, and climate. Small changes in the SOC pool therefore can have large implications for atmospheric $\mathrm{CO}_{2}$ concentrations (Simo et al. 2010; Theurillat et al. 1998).

The rapidly increasing population pressure on the highlands of Ethiopia has led to vast changes in land use pattern mainly caused by increasing agricultural production. In this region, cultivated lands showed slow but continuously increasing trend at the expense of forest and grasslands over the last four decades (Kidanu and Mamo 2003; Eshetu et al. 2004). Even though Gebrehiwot et al. (2013) has been quantified the forest land changes in Birr watershed in the Blue Nile Basin and discussed the drivers for the changes, the authors did not provide the information on the variation of the soil organic carbon in relation to land use changes. On the other hand, soil organic carbon content exhibits considerable variability spatially, both horizontally according to land use and vertically within the soil profile. The SOC diminishes with depth regardless of vegetation, soil texture, and clay size fraction (Trujilo et al. 1997). Soils of the world are potentially viable sinks for atmospheric carbon and may significantly contribute to mitigate the global climate change (Singh and Lal 2001). However, Susmita (Dhakal, S.: Land use change effect on soil carbon stock. Kirtipur: MSc. Thesis, Tribhuvan University, unpublished) indicated that the assessment of potential carbon sequestration in soil requires estimating carbon pools under existing land uses and its depth wise distribution in the soil profile.

The objective of the study was to describe the variations in the SOC concentration and stock in relation to different land use types within Birr watershed, Upper Blue Nile ('Abbay') Basin, North-Western Ethiopia. Hence, the specific research questions to be addressed in this study are (1) what is the influence of land use types on SOC stock? (2) How does SOC stock vary with soil depth? And (3) how SOC stock related to the other soil variables such as soil textural fractions, moisture content, and bulk density at different soil depths?

\section{Methods \\ Study site description}

The study was conducted in the Birr watershed at middle of the 'Abbay' river basin geographically located within $10.5^{\circ}-11.25^{\circ}$ North and $37.25^{\circ}-37.75^{\circ}$ East (Fig. 1). It covers an area of $\sim 1170 \mathrm{~km}^{2}$ (Solomon N: Error in highresolution satellite rainfall production in stream flow prediction in Birr watershed, Ethiopia, unpublished).

The mean annual rainfall recorded was $1730 \mathrm{~mm}$ (averages from 1960 to 2004) with mono-modal rainfall (Gebrehiwot et al. 2013). The mean maximum and minimum annual temperature of the watershed were $29.6^{\circ}$ and $14.0{ }^{\circ} \mathrm{C}$, respectively. The watershed was characterized by a complex terrain dominated by high elevation which ranges from 1771 to $3257 \mathrm{~m}$ above sea level. The Luvisols dominates the watershed while Cambisols are present in small portion in the catchment (Solomon $\mathrm{N}$ : Error in high-resolution satellite rainfall production in stream flow prediction in Birr watershed, Ethiopia, unpublished). The area is well known by rain-fed cereal crop production. The main crops are maize (Zea mays L.), wheat (Triticum aestivum L.), teff (Eragratis teff), sorghum (Sorghum bicolor L.), finger millet (Eleusine coracana), and potato (Solanum tuberrosum Linnaeus) in addition to pulses and oil crops (Sinamaw A: Land use land cover change and its driving factors: A case of Birr watershed, upper Blue Nile river basin, Ethiopia. Ethiopia: Msc. Thesis, Hawassa University, unpublished).

Two decades ago, the cultivation land covered the largest part of the Birr watershed (ca. 514.8 ha, and 44\% of total watershed area). Other wooded and grasslands were found to be the second largest land use types covering 397.8 ha (34\% of total watershed area) while forest 


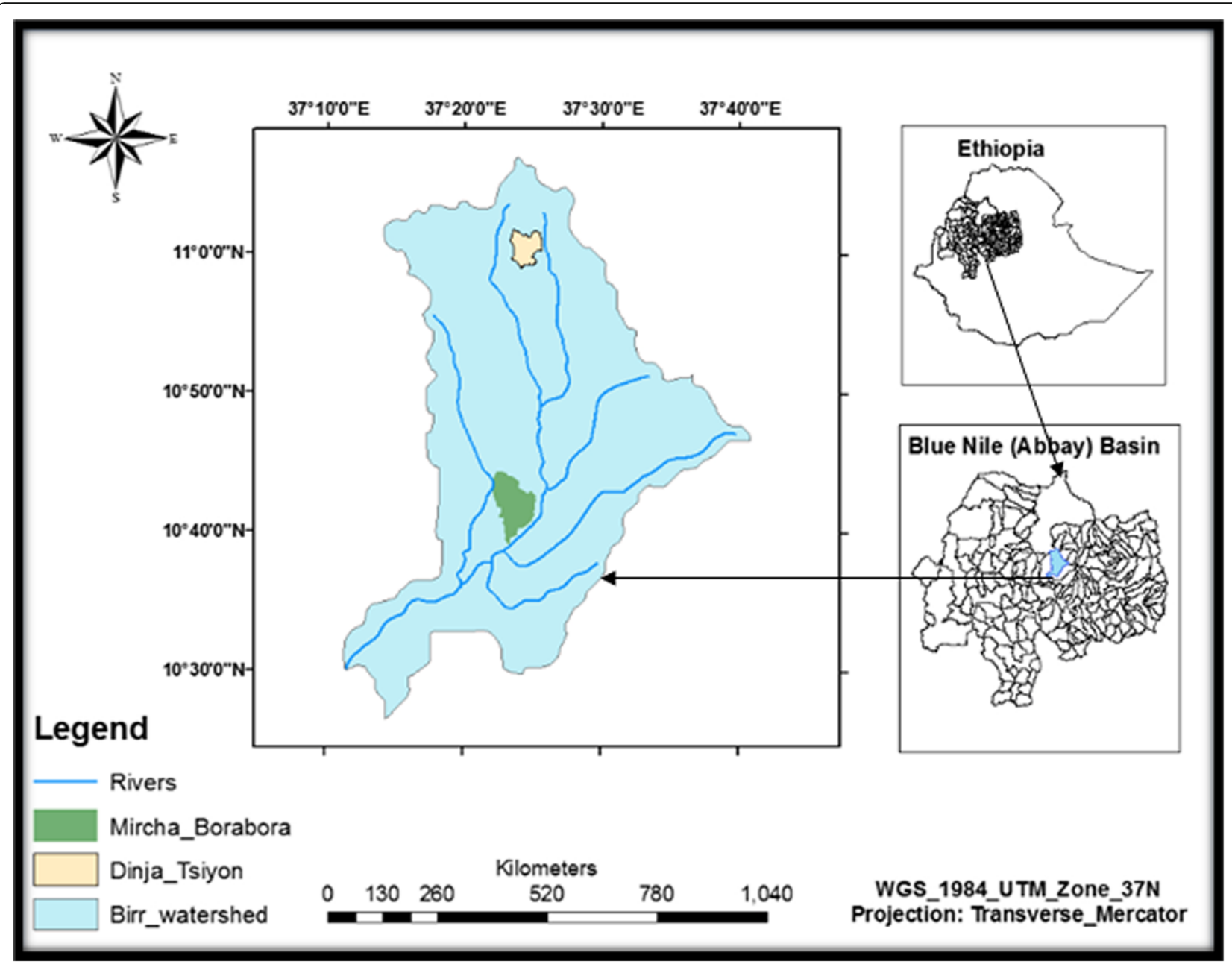

Fig. 1 Geographical location of study site in map of Ethiopia

land covers 152.1 ha (13\%) and the Eucalyptus plantation covers about 105.3 ha (9\%) of the total watershed area (Gebrehiwot et al. 2013).

\section{Land use classification}

The current study on the Birr watershed was ultimately targeted on carbon stock change estimation. Consequently, the classification has been slightly adapted to include FAO standards, without losing the opportunity of some comparison with the study of Gebrehiwot et al. (2013). The four main strata have been used for allocation of various samples, while the sub-category has been used during land use classification.

1. Natural forest: includes all forest land spanning more than 0.5 ha with trees higher than $5 \mathrm{~m}$ and a canopy cover of more than $10 \%$, or trees able to reach these thresholds in situ. It does not include land that is predominantly under agricultural or urban land use. Its subcategories include

- Dry mixed deciduous forest: evergreen and deciduous forest in areas where annual rainfall is $1500 \mathrm{~mm}$.

- Other natural forest: includes riverine forest and any other natural forests.

2. Plantation forest: includes forest plantations and wood lots spanning more than 0.05 ha with trees higher than $5 \mathrm{~m}$ and a canopy cover of more than $10 \%$, or trees able to reach these thresholds in situ. It does not include land that is predominantly under agricultural or urban land use. Its subcategories include

- Eucalyptus plantations: plantations dominated by Eucalyptus species

- Other plantations: plantations dominated by other species than Eucalyptus

3. Other wooded land and grass land: land not classified as "forest," spanning more than 0.5 ha 
with a tree cover less than $10 \%$. It does not include land that is predominantly under agricultural or urban land use. Its subcategories include

- Other wooded land: land not classified as "forest" or predominantly under agriculture and which has a combined cover of shrubs, bushes, and trees exceeding $10 \%$.

- Grassland: land not classified as forest or predominantly under agriculture which is under grass cover and has a combined cover of trees and bushes less than $10 \%$.

4. Cultivated land: its subcategories include:

- Crop land: land under continuous or seasonal crop cultivation.

- Residential areas: land covered by living houses, home gardens, offices, and market places.

\section{Methodological approaches \\ Site selection criteria}

The following criteria were fulfilled to construct a soil sampling design: objective selection of sampling plots, possibility to study effects of land use change on soil carbon, and possibility to get average carbon content of soils under different land uses in the area.

\section{Selection of sampling sites}

The field observation and soil sampling (according to sampling design from different land uses) was carried out starting from 9 February to 8 March, 2015 for a month in the study watershed. Sampling was done in two kebeles, one in the down-stream and one in the up-stream part of the catchment. Four types of land use classes were considered: cultivated land, open bush land, natural and mixed forest (fulfilling the FAO forest definition) and Eucalypt plantations. These four groups were consistent with the ones that Gebrehiwot et al. (2013) used in his study. The sampling was stratified to transitions between land uses, and an equal number of samples were taken on each land use, i.e., the sampling was not being proportional to the area covered by each land use. The sampling plots were selected along transects in the landscape and potential sampling points are located when transect crosses a border between two land use/land cover classes. Sampling was taken from place $10 \mathrm{~m}$ before and $10 \mathrm{~m}$ after the border between the land uses. The potential sampling points along transects were identified in Google earth and when all potential points were being identified, a random selection was done so that 37 paired points were found that given 74 sample points. Hence, total of 148 soil samples were collected for the whole study and analyzed at Wondo Genet
College of Forestry and Natural Resources Soil Laboratory, Hawassa University.

\section{Laboratory analysis}

Before soil chemical analysis has carried out, air-dried soil samples were pounded with pestle and mortal, and passed through a $2 \mathrm{~mm}$ sieve. Then, soil textural analysis was determined through hydrometer method (Bouyoucos 1962) while moisture content in the soil was determined by the percentage weight loss of soil sample after it was oven-dried at $105{ }^{\circ} \mathrm{C}$ divided by the dried soil weight in gram according to ICARDA (2013). On the other hand, the bulk density analysis was determined by using core sampling method that each sample was dried at $105^{\circ} \mathrm{C}$ for a minimum of $48 \mathrm{~h}$ according to Blake and Hartge 1986. The soil $\mathrm{pH}$ was measured potentiometrically in the supernatant suspension of a 1:2.5 $(w / v)$ soil-water ratio by using a pH meter (Carter 1993; Karaoz 1989). Soil organic carbon concentration in the soil samples was determined according to Walkley and Black (1934). Finally, soil organic carbon stock was determined for every depth of land use/land cover types according to Lemma et al. (2006).

$$
\begin{aligned}
& \text { Soil organic carbon (SOC)stock } \\
& \quad=z * \rho \mathrm{b} * \mathrm{SOC} \text { concentration }(\mathrm{g} / \mathrm{kg}) * 10
\end{aligned}
$$

Where; Soil organic carbon (SOC) stock ( $\left.\mathrm{Mg} \mathrm{ha}^{-1}\right) ; z$ $=$ sampled soil layer thickness $(m)$; and $\rho \mathrm{b}=$ bulk density $\left(\mathrm{Mg} \mathrm{m}^{-3}\right)$.

\section{Statistical analysis}

First test for normality ('kolmogorov-Smirnov') and equality of variance ('Levene statistic') for the properties of the soil were conducted. The ANOVA models were utilized to compare the effect of land uses and soil depth depending on soil physiochemical properties using the general linear model (proc GLM with Tukey's HSD) procedures of SAS software (SAS Institute 2002). Pearson's correlation coefficients and regression equations were tested for significance using $p<0.05$ as a criterion for significance. Pairwise comparison method was also used to assess the mean difference of the land uses and depth levels depending on soil properties. The mean square error (R) was obtained by adding the square of differences between the observed and the mean of the dependent variables and dividing it to residual degree of freedom. The multiple comparisons of means for each class variable (among land uses, depth, moisture content, bulk density, soil organic carbon) was carried out using the DUNCAN test at $\alpha=0.05$.

Variation in the soil physiochemical properties across land uses and soil depth were computed by taking the forest land use and 0-15 cm soil depth as reference groups 
respectively. Hence, for a given physiochemical soil property, the variation expresses how much it increased in percent in relation to the reference group. For example, the variation (\%) for cultivated land and 15-30 cm soil depth for a given physiochemical soil property were computed as

$$
\begin{aligned}
& \text { Variation }_{\text {Cultivated land }}(\%) \\
& \qquad=\left[\frac{\text { Value }_{\text {Cultivated land }}-\text { Value }_{\text {Mixednatural forest }}}{\text { Value }_{\text {Mixednatural forest }}}\right] * 100
\end{aligned}
$$

Variation $_{15-30 \mathrm{~cm}}(\%)$

$$
=\left[\frac{\text { Value }_{15-30 \mathrm{~cm}}-\text { Value }_{0-15 \mathrm{~cm}}}{\text { Value }_{0-15 \mathrm{~cm}}}\right] * 100
$$

\section{Result and discussion}

\section{Effect of land use change on the soil physical properties} Soil textural fractions

The soil textural fractions of sand $(p=0.0223)$ and clay $(p=0.0447)$ showed significant variation with land use/ land cover types (Table 1). No significant difference was observed in silt fraction across all land use types. The sand fraction was higher in the natural and mixed forest land $(60.7 \pm 5.74)$ followed by open- and bush land (59.3 \pm 5.74 ) compared to other land use types (Table 1). The overall mean sand fraction was lower under cultivated land $(33.8 \pm 5.74)$ compared to other land use types (Table 3). On the other hand, cultivated land had higher clay fraction $(38.8 \pm 5.23)$ compared to other land use types. Sandy clay loam is the dominant textural class in the in the $0-10$ and $10-20 \mathrm{~cm}$ soil depths under Eucalyptus plantation and open-bush land while sandy loam throughout the soil layers under the natural and mixed forest. The results indicated that soil textural fractions responded differently following conversion of natural and mixed forest to other land use types. Sand fraction under natural and mixed forest, and open-bush land was higher compared with other land use types. This might be attributed to the high precipitation conditions, which remove the fine particles, i.e., silt and clay fractions in agreement with Yuksek et al. (2009), Yimer et al. (2007), and (Getachew, F: Effects of land use types on soil physical and chemical properties in Wondo Genet, Ethiopia. Ethiopia: MSc. Thesis, Hawassa University, unpublished) in that the high proportions of sand in the study area was related to the impact of soil erosion process due to high rainfall, which has selectively transported the fine soil particles and leaving behind the coarser ones. The overall mean sand fraction under cultivated land was $34.5 \%$ lower than other land uses while clay fraction was higher by $36.5 \%$. The increase in clay fractions with depth in the studied soils might be related to clay translocation from the upper soil layer to the layer below and clay formation due to on-going weathering processes in the of soil profile (Yimer et al. 2006). Similarly, Jaiyeoba (1998) indicated the effects of leaching on clay fraction distribution with depths.

\section{Soil moisture content}

There was no significant moisture content variation with land use types $(p=0.063$; Table 2$)$. The results showed that overall mean soil moisture content was slightly higher under Eucalyptus plantation $(19.66 \pm 0.8)$ compared with other land use types. The soil moisture content showed significant difference with soil depth $(p<0.0001$; Table 1$)$. It was higher under natural and mixed forest land use $(21.72 \pm 1.4)$ than other land use types while lowest was observed in soil under cultivated land $(15.37 \pm 0.9)$ use in the $10-20$ and $0-10 \mathrm{~cm}$ soil depth, respectively.

Overall, mean soil moisture content was 13.36\% higher under Eucalyptus plantation compared to cultivated land. This could be due to the prevalence of relatively lower amount of evapo-transpiration anticipated from the Eucalyptus plantation, and natural and mixed forest land uses. This result confirms with the finding of (Kassahun, H. T.,

\begin{tabular}{|c|c|c|c|c|c|c|}
\hline \multirow[t]{2}{*}{ Response variables } & \multirow[t]{2}{*}{ Soil depth (cm) } & \multicolumn{4}{|l|}{ Land uses } & \multirow[t]{2}{*}{ Overall } \\
\hline & & Natural and mixed forest & Cultivated land & Eucalyptus plantation & Open bush land & \\
\hline \multirow[t]{3}{*}{$\mathrm{pH}$} & $0-10$ & $5.83 \pm 0.1^{\mathrm{A}}$ & $5.52 \pm 0.1^{\mathrm{AB}}$ & $5.41 \pm 0.1^{\mathrm{B}}$ & $5.34 \pm 0.1^{B}$ & $5.53 \pm 0.06$ \\
\hline & $10-20$ & $5.82 \pm 0.1^{\mathrm{A}}$ & $5.49 \pm 0.1^{B}$ & $5.22 \pm 0.1^{B}$ & $5.34 \pm 0.1^{B}$ & $5.47 \pm 0.06$ \\
\hline & Overall & $5.83 \pm 0.1^{\mathrm{A}}$ & $5.51 \pm 0.07^{B}$ & $5.32 \pm 0.08^{B}$ & $5.34 \pm 0.07^{B}$ & \\
\hline \multirow[t]{3}{*}{ SOC (\%) } & $0-10$ & $4.58 \pm 0.31^{\mathrm{A}}$ & $2.33 \pm 0.22^{B}$ & $2.71 \pm 0.24^{B}$ & $2.77 \pm 0.23^{B}$ & $3.10 \pm 0.13$ \\
\hline & $10-20$ & $2.66 \pm 0.31^{\mathrm{A}}$ & $1.6 \pm 0.22^{B}$ & $2.03 \pm 0.24^{B}$ & $1.7 \pm 0.23^{B}$ & $1.99 \pm 0.13$ \\
\hline & Overall & $3.62 \pm 0.22^{\mathrm{A}}$ & $1.97 \pm 0.16^{\mathrm{B}}$ & $2.37 \pm 0.17^{B}$ & $2.23 \pm 0.16^{B}$ & \\
\hline SOC & $0-10$ & $36.9 \pm 2.76^{\mathrm{A}}$ & $22.71 \pm 1.95^{B}$ & $25.09 \pm 2.14^{B}$ & $26.95 \pm 2.04^{B}$ & $27.91 \pm 1.12$ \\
\hline \multirow[t]{2}{*}{$\left(\mathrm{Mg} \mathrm{ha}^{-1}\right)$} & $10-20$ & $22.35 \pm 2.76^{A}$ & $15.12 \pm 1.95^{B}$ & $17.78 \pm 2.14^{B}$ & $15.49 \pm 2.04^{B}$ & $17.69 \pm 1.12$ \\
\hline & Overall & $29.62 \pm 1.95^{\mathrm{A}}$ & $18.92 \pm 1.38^{B}$ & $21.44 \pm 1.51^{B}$ & $21.22 \pm 1.44^{B}$ & \\
\hline
\end{tabular}
Engda, T. A., Collick, A. S., Oumer, H. A., Bayabil, H. K.,

Table 1 Mean ( \pm standard error) of the soil chemical properties across land uses $(0-20 \mathrm{~cm})$

The mean values followed by the different letters across rows are significantly different $(p<0.05)$ 
Table 2 Summary of two-way ANOVA results for the soil physical properties in relation to land use and soil depths $(0-20 \mathrm{~cm})$

\begin{tabular}{|c|c|c|c|c|c|c|c|c|c|c|c|}
\hline \multirow{2}{*}{$\begin{array}{l}\text { Source of } \\
\text { variation }\end{array}$} & \multirow[t]{2}{*}{ D.F } & \multicolumn{2}{|l|}{ Sand } & \multicolumn{2}{|l|}{ Silt } & \multicolumn{2}{|l|}{ Clay } & \multicolumn{2}{|c|}{ Moisture content } & \multicolumn{2}{|c|}{ Bulk density } \\
\hline & & MS & p & MS & $p$ & MS & $p$ & MS & $p$ & MS & $p$ \\
\hline$\overline{L U}$ & 3 & 917.597 & 0.0223 & 73.153 & 0.3999 & 597 & 0.0447 & 59.288 & 0.0632 & 0.124 & $<0.0001$ \\
\hline Depth & 1 & 1.5 & 0.9924 & 75.042 & 0.3662 & 95.042 & 0.5749 & 408.126 & $<0.0001$ & 0.044 & 0.0202 \\
\hline $\mathrm{LU}^{*}$ depth & 3 & 37.222 & 0.9743 & 13.653 & 0.9707 & 14.542 & 0.9963 & 12.259 & 0.6738 & 0.009 & 0.3603 \\
\hline Mean & & 51.6 & & 23.7 & & 24.7 & & 18.38 & & 0.926 & \\
\hline R-square & & 0.557 & & 0.354 & & 0.513 & & 0.149 & & 0.281 & \\
\hline Error & 148 & 197.542 & & 68.625 & & 163.917 & & 23.889 & & 0.0081 & \\
\hline
\end{tabular}

$L U$ and $M S$ stand for the land use land cover and mean of square, respectively

Tebebu, T. Y., Zewdie, A. A., Solomon, D., Nicholson, C. F., \& Steenhuis, T. S.: The effect of land use and its management practices on plant nutrient availability and carbon sequestration. Ethiopia: MSc Thesis, BahirDar University, unpublished) who reported that cultivated land is lower in moisture content due to continued plowing and complete exposure for high solar radiation, which will result in loss of significant soil moisture. The mean moisture content significantly increased with $16.56 \%$ with soil depth. It was found to be higher in the $10-20 \mathrm{~cm}$ under natural and mixed forest land use and lower under cultivated land in the $0-10 \mathrm{~cm}$ soil depth.

\section{Soil bulk density}

The land use types significantly $(p<0.0001)$ affected the soil bulk density (Table 1$)$. It was higher under cultivated land $(0.97 \pm 0.013)$ followed by open bush land $(0.95 \pm$ 0.014 ) compared with other land use types. Bulk density in soil under natural and mixed forest land use type was found to be the lowest $(0.83 \pm 0.018)$. The soil bulk density showed significant variation with soil depth $(p=0.0202$; Table 2). It has shown a decreasing trend except in soil under natural and mixed forest land use types. On the other hand, the bulk density in the top 0-10 cm was lower under natural and mixed forest $(0.819 \pm 0.02)$ than other land uses (Table 3).

The lower bulk density under natural and mixed forest land use compared to others could be related to the higher organic matter content which increases the soil volume without affecting its weight. This is a result that is similar to findings in Takele et al. (2015) and Fantaw and Abdu (2011). They reported that the lower bulk density in the soil under forest and the higher bulk density in soils under cultivated land were attributed to the differences in soil organic matter and less disturbances under forest land use than in the cultivated land. On the other hand, higher bulk density in cultivated land could be attributed to the impact of repeated tillage which

Table 3 Mean ( \pm standard error) of the soil physical properties across land uses $(0-20 \mathrm{~cm})$

\begin{tabular}{|c|c|c|c|c|c|c|}
\hline \multirow[t]{2}{*}{ Response variables } & \multirow[t]{2}{*}{ Soil depth (cm) } & \multicolumn{4}{|l|}{ Land uses } & \multirow[t]{2}{*}{ Overall } \\
\hline & & Natural and mixed forest & Cultivated land & Eucalyptus plantation & Open bush land & \\
\hline \multirow[t]{3}{*}{ Sand (\%) } & $0-10$ & $66 \pm 9.93^{A}$ & $35.5 \pm 9.93^{B}$ & $50.5 \pm 9.93^{\mathrm{A}}$ & $55.5 \pm 9.93^{\mathrm{A}}$ & $51.9 \pm 4.97$ \\
\hline & $10-20$ & $60 \pm 9.93^{A}$ & $34 \pm 9.93^{B}$ & $50.5 \pm 9.93^{A}$ & $63 \pm 9.93^{A}$ & $51.9 \pm 4.97$ \\
\hline & Overall & $60.67 \pm 5.74^{A}$ & $33.83 \pm 5.74^{B}$ & $52.67 \pm 5.74^{\mathrm{A}}$ & $59.33 \pm 5.74^{\mathrm{A}}$ & \\
\hline \multirow[t]{3}{*}{ Silt (\%) } & $0-10$ & $19 \pm 5.86^{A}$ & $28.5 \pm 5.86^{A}$ & $29 \pm 5.86^{A}$ & $30 \pm 5.86^{A}$ & $26.8 \pm 2.93$ \\
\hline & $10-20$ & $18.5 \pm 5.86^{\mathrm{A}}$ & $28 \pm 5.86^{A}$ & $23.5 \pm 5.86^{\mathrm{A}}$ & $25 \pm 5.86^{A}$ & $23.8 \pm 2.93$ \\
\hline & Overall & $19.00 \pm 3.38^{A}$ & $27.33 \pm 3.38^{A}$ & $23.67 \pm 3.382^{\mathrm{A}}$ & $24.83 \pm 3.38^{\mathrm{A}}$ & \\
\hline \multirow[t]{3}{*}{ Clay (\%) } & $0-10$ & $14.5 \pm 9.05^{\mathrm{B}}$ & $36 \pm 9.05^{A}$ & $20.5 \pm 9.05^{\mathrm{AB}}$ & $14.5 \pm 9.05^{\mathrm{B}}$ & $21.4 \pm 4.527$ \\
\hline & $10-20$ & $21.5 \pm 9.05^{\mathrm{B}}$ & $38 \pm 9.05^{A}$ & $26 \pm 9.05^{\mathrm{AB}}$ & $12 \pm 9.05^{B}$ & $24.4 \pm 4.527$ \\
\hline & Overall & $20.67 \pm 5.23^{B}$ & $38.83 \pm 5.23^{\mathrm{A}}$ & $23.67 \pm 5.23^{A B}$ & $15.83 \pm 5.26^{\mathrm{B}}$ & \\
\hline \multirow[t]{3}{*}{$M C(\%)$} & $0-10$ & $17.11 \pm 1.41^{\mathrm{A}}$ & $15.37 \pm 0.99^{A}$ & $18.79 \pm 1.09^{\mathrm{A}}$ & $16.24 \pm 1.04^{\mathrm{A}}$ & $16.88 \pm 0.57$ \\
\hline & $10-20$ & $21.72 \pm 1.41^{\mathrm{A}}$ & $18.76 \pm 0.99^{A}$ & $20.52 \pm 1.09^{A}$ & $19.95 \pm 1.04^{\mathrm{A}}$ & $20.23 \pm 0.57$ \\
\hline & Overall & $19.42 \pm 0.99^{A}$ & $17.06 \pm 0.70^{A}$ & $19.66 \pm 0.77^{A}$ & $18.1 \pm 0.74^{A}$ & \\
\hline \multirow[t]{3}{*}{$\mathrm{BD}\left(\mathrm{g} \mathrm{cm}^{-3}\right)$} & $0-10$ & $0.819 \pm 0.03^{B}$ & $1.000 \pm 0.02^{\mathrm{A}}$ & $0.936 \pm 0.02^{A}$ & $0.969 \pm 0.02^{A}$ & $0.931 \pm 0.01$ \\
\hline & $10-20$ & $0.836 \pm 0.03^{C}$ & $0.945 \pm 0.02^{A}$ & $0.877 \pm 0.02^{B C}$ & $0.925 \pm 0.02^{\mathrm{AB}}$ & $0.896 \pm 0.01$ \\
\hline & Overall & $0.828 \pm 0.02^{C}$ & $0.973 \pm 0.02^{A}$ & $0.906 \pm 0.01^{B}$ & $0.947 \pm 0.02^{\mathrm{AB}}$ & \\
\hline
\end{tabular}


disturbs the soil structure, causing a compacted surface soil layer. This is in agreement with Kizilkaya and Dengiz (2010) in that loss of organic matter by conversion of natural forest into cultivated land has resulted in a higher bulk density. Similar results were reported by Islam and Weil (2000) that continuous tillage practice has result an increase in soil bulk density.

The soil bulk density showed significant variation with the soil depth. The higher bulk density was observed in the surface soil across all land uses which could be due to the effect of moisture content and soil texture on bulk density. The Pearson correlation coefficient showed that bulk density was inversely correlated with moisture content $(p=0.01)$ and positively correlated with silt fraction $(p=0.05)$. This implies that the higher moisture content and lower silt fraction results in lower bulk density. On the other hand, bulk density might be influenced by clay fraction of soil texture. This result is similar to Askin and Ozdemir (2003) who reported that a unit increases in organic matter and clay content caused a relative decrease in soil bulk density. Fantaw and Abdu (2011) reported that application of organic materials from the plant system leads to a decrease in the surface soil bulk density than the layer below. Yimer et al. (2006) also indicated that the compaction resulting from the weight from the top layer might be the reason for the increased bulk density in the lower layer.

\section{Effect of land use change on soil chemical properties Soil $\mathrm{pH}\left(\mathrm{H}_{2} \mathrm{O}\right)$}

The soil $\mathrm{pH}$ was significantly affected by land use types $(p=0.0003$; Table 4). The results indicated that the mean soil $\mathrm{pH}$ was 5.4 and ranged from 5.83 to 5.22 across land uses. Results showed that the overall mean soil $\mathrm{pH}$ under natural and mixed forest was significantly higher $(p=0.0003,5.83 \pm 0.1)$ and lower under Eucalyptus plantation $(5.32 \pm 0.1)$ compared with other land uses in the $0-20 \mathrm{~cm}$ soil depth. Results revealed that there was no significant variation in soil $\mathrm{pH}$ with soil depth $(p=0.474$; Table 5). However, it was confirmed that the mean $\mathrm{pH}$ value was higher under natural and mixed forest $(p=$

Table 4 Summary of two-way ANOVA results for the soil chemical properties in relation to land use and soil depths $(0-20 \mathrm{~cm})$

\begin{tabular}{|c|c|c|c|c|c|c|c|}
\hline \multirow{2}{*}{$\begin{array}{l}\text { Source of } \\
\text { variation }\end{array}$} & \multirow[t]{2}{*}{ D.F } & \multicolumn{2}{|c|}{$\mathrm{pH}\left(\mathrm{H}_{2} \mathrm{O}\right)$} & \multicolumn{2}{|c|}{ SOC content } & \multicolumn{2}{|c|}{ SOC stock } \\
\hline & & $\overline{M S}$ & p & $\overline{M S}$ & $p$ & $\overline{M S}$ & $p$ \\
\hline LULC & 3 & 1.588 & 0.0003 & 15.306 & $<0.0001$ & 629.084 & 0.0002 \\
\hline Depth & 1 & 0.125 & 0.4741 & 43.901 & $<0.0001$ & 3797.15 & $<0.0001$ \\
\hline LULC ${ }^{*}$ depth & 3 & 0.08 & 0.8027 & 2.363 & 0.1085 & 95.518 & 0.375 \\
\hline Mean & & 5.46 & & 2.4 & & 21.86 & \\
\hline$R$-square & & 0.125 & & 0.35 & & 0.301 & \\
\hline Error & 148 & 0.243 & & 1.149 & & 91.497 & \\
\hline
\end{tabular}

LULC and MS stands for the land use land cover and mean of square, respectively
$0.045,5.83 \pm 0.1)$ while lower in the Eucalyptus plantation $(p=0.009,5.22 \pm 0.1)$ compared with other land uses in $0-10$ and $10-20 \mathrm{~cm}$ soil depths, respectively.

It was found that soil acidity was significantly higher in the Eucalyptus plantation than in other land uses. This is likely due to the acidifying effect of Eucalyptus trees. Sasikumar et al. (2002) indicated that the phenolic acids and volatile oils released from the leaves, bark, and roots of certain Eucalyptus species have deleterious effects on other plant species. This finding is similar to Eshete et al. (2011) who reported that most of Eucalyptus species have acidifying effect on the soil properties. On the other hand, the higher acidity (lower $\mathrm{pH}$ ) in cultivated land compared with forest land was probably due to continuous removal of basic cations by crops, crops' harvest enhanced leaching of basic cations, and washed away of exchangeable bases by soil erosion. This result is consistent with Gebrekidan and Negassa (2006) who reported that land use and management practices have remarkably influenced the soil $\mathrm{pH}$.

There was no significant variation on soil acidity with the soil depths. However, the soil pH value in the Eucalyptus plantation showed a decreasing trend (3.5\%) with soil depth. This might be related to the selective pumping of bases from the layer below through perennial plant roots which gradually release base cations. This is in agreement with Kidanemariam et al. (2012) and Fantaw and Abdu (2011) who stated that the continuous release of basic cations from the slow decomposition of organic residues and deposition of bases at the surface by the deep rooting of forest trees from the subsoil.

\section{Soil organic carbon concentration}

The SOC concentration showed significant difference with land use types $(p<0.0001$; Table 4$)$. The overall mean SOC concentration was higher under natural and mixed forest $(p<0.0001,3.62 \pm 0.22)$ and lower under cultivated land $(1.97 \pm 0.16)$ compared with other land uses. The mean SOC concentration also showed a significant difference with soil depth $(p<0.0001$; Table 4$)$. The mean SOC concentration was higher under natural and mixed forest land use $(p=0.0001,4.58 \pm 0.31)$ and lower in soil under cultivated land $(p=0.0004,1.6 \pm 0.22)$ than other land use types in the $0-10$ and $10-20 \mathrm{~cm}$ soil depth, respectively. Generally, it has a decreasing trend with soil depth (Table 6).

It was found that mean SOC content under natural and mixed forest was $45.58,38.39$, and $34.53 \%$ higher than that of cultivated, open-bush land, and Eucalyptus plantation, respectively. This could be due to removal of the crop residues from cultivated land during crop harvesting and continuous tillage practice. Under cereal land cultivation, the low SOC content may be due to frequent harvesting by crops which thereby perpetually remove the nutrients from the soil (Fermont et al. 2008; Haileslassie et al. 2005). The removal of the crop remains (Haileslassie et al. 2005) 
Table 5 Variation (\%) (difference) in soil properties within 0-20 cm soil depth between cultivated land, Eucalyptus plantation, and open- and bush land as compared to natural and mixed forest in the watershed

\begin{tabular}{|c|c|c|c|}
\hline \multirow[t]{2}{*}{ Soil properties } & \multicolumn{3}{|l|}{ Land uses } \\
\hline & Cultivated land & Eucalyptus plantation & Open bush lanc \\
\hline Sand (\%) & $-44.24(26.84)^{*}$ & $-13.19(8.0)^{\text {N.S }}$ & $-2.21(1.34)^{\mathrm{N} . \mathrm{S}}$ \\
\hline Clay (\%) & $46.78(18.16)^{*}$ & $12.67(3.0)^{\mathrm{N} . \mathrm{S}}$ & $-23.42(4.84)^{\mathrm{N} . S}$ \\
\hline Moisture content (\%) & $-12.15^{\mathrm{N} . \mathrm{S}}$ & $1.24^{\mathrm{N} . \mathrm{S}}$ & $-6.79^{\mathrm{N} . S}$ \\
\hline Bulk density $\left(\mathrm{g} \mathrm{cm}^{-3}\right)$ & $17.51^{* *}$ & $9.42^{* *}$ & $14.37^{* *}$ \\
\hline $\mathrm{pH}\left(\mathrm{H}_{2} \mathrm{O}\right)$ & $-5.49^{* *}$ & $-8.75^{* *}$ & $-8.40^{* *}$ \\
\hline SOC concentration (\%) & $-45.58(1.67)^{* *}$ & $-34.53(1.25)^{* *}$ & $-38.39(1.39)^{* *}$ \\
\hline SOC stock (Mg ha $\left.{ }^{-1}\right)$ & $-36.12(10.7)^{* *}$ & $-27.62(8.18)^{* *}$ & $-28.36(8.40)^{* *}$ \\
\hline
\end{tabular}

N.S. stands for not significant; ${ }^{* *}$ and * are significant at 1 and 5\%, respectively

for cooking and animal feed almost leaves no biomass to be returned to the soil. The small-sized nature of the major crops grown ('teff' and wheat) in the study area is another constraint for the nutrient return to the soil through plant remains, a determinant source for labile carbon (Hooker and Stark 2008). Cultivation also exposes the available organic matter to moisture (Reicosky and Forcella 1998), aeration, and other decomposing agents, facilitating the fast degradation and mineralization (Wild 2003) of the available organic matter thereby reducing the soil carbon. The frequent (Shisanya et al. 2008), i.e., intense utilization of farmlands (Murage et al. 2000) due to land shortage is another factor for the diminishing quality of the farmlands as the crops remove substantial amount of nutrients (Fermont et al. 2008) with minimal return rate every year.

The SOC concentration was influenced by soil depth and showed decreasing trend with depth. Assuming that the native forest sites are appropriate ecological references, croplands through forest clearance has released about $65.1 \%$ of the carbon concentration originally accumulated in the top surface layers of soil under natural and mixed forest followed by open bush land (62.9\%) and Eucalyptus plantation which has released about $55.7 \%$. As soil depth considered, it declined by $41.92 \%$ under natural and mixed forest and $38.63 \%$ under open bush land. On the other hand, the lowest decline in SOC concentration was observed under Eucalyptus plantation; which was about $25.09 \%$ followed by cultivated land (-31.33\%).

The lower SOC concentration found in the deeper layer could be related to the reduced amount of the external inputs in to the soil. This is consistent with Alemayehu et al. (2010) who reported animal wastes and inorganic fertilizers temporarily remain in the top surface soil rather than going deeper. According to (Nagy, R. C.: Impact of land use/cover on ecosystem carbon storage in Apalachicola. Auburn: Msc Thesis, Miami University, unpublished), there could be noticeable change in organic matter in the surface horizon and rooting zone of fine-textured soils due to the tendency of fine particles to bind tightly with organic matter; thus, fine-textured soils are more likely to accumulate dissolved organic matter (Sanchez et al. 2006). Others have seen declines in soil carbon in coarse-textured soils because of the inability of coarse particles to protect the organic matter in the soil aggregates (Vance 2000).

\section{Conversion effect of land use on carbon stocks}

The results showed that mean SOC stock was highly influenced by the land uses $(p=0.0002$; Table 4$)$. The overall mean SOC stock was found to be higher under natural and mixed forest land $(p=0.0002,29.62 \pm 1.95)$ and lower in soils under cultivated land $(18.92 \pm 1.38)$ than other land use types. On the other hand, the SOC stock was highly influenced by soil depth $(p<0.0001$; Table 4$)$. The

Table 6 Variation (\%) in soil properties between 10 and $20 \mathrm{~cm}$ and $0-10 \mathrm{~cm}$ soil depth compared to values of 0-10 cm soil depth in the watershed

\begin{tabular}{|c|c|c|c|c|}
\hline \multirow[t]{2}{*}{ Soil properties } & \multicolumn{4}{|l|}{ Land uses } \\
\hline & Natural and mixed forest & Cultivated land & Eucalyptus plantation & Open- and bush land \\
\hline Moisture content (\%) & $26.94^{*}$ & $22.06^{*}$ & $9.21^{*}$ & $22.84^{*}$ \\
\hline Bulk density $\left(\mathrm{g} \mathrm{cm}^{-3}\right)$ & $2.08^{*}$ & $-5.5^{*}$ & $-6.3^{*}$ & $-4.54^{*}$ \\
\hline $\mathrm{pH}\left(\mathrm{H}_{2} \mathrm{O}\right)$ & $-0.17^{\mathrm{N} . \mathrm{S}}$ & $-0.54^{\mathrm{N} . \mathrm{S}}$ & $-3.51^{\mathrm{NS}}$ & - \\
\hline SOC concentration (\%) & $-41.92^{*}$ & $-31.33^{*}$ & $-25.09^{*}$ & $-38.63^{*}$ \\
\hline SOC stock (Mg ha $\left.{ }^{-1}\right)$ & $-39.43^{*}$ & $-33.42^{*}$ & $-29.14^{*}$ & $-42.52^{*}$ \\
\hline
\end{tabular}


mean SOC stock was higher under natural and mixed forest land use $(p=0.011,36.9 \pm 2.76)$ and lower in soil under cultivated land $(p=0.013,15.12 \pm 1.95)$ compared with other land use types in the $0-10$ and 10-20 soil depth, respectively (Table 1). It was found that SOC stock under natural and mixed forest was $36.12 \%$ more than cultivated land followed by the open bush land (28.36\%) and Eucalyptus plantation $(-27.62 \%)$. The SOC stock follows the pattern: natural and mixed forest $>$ Eucalyptus plantation > open- and bush-land > cultivated land.

The SOC stock also significantly varied with soil depth and showed a decreasing trend. Assuming that the native forest sites are appropriate ecological references, croplands through forest clearance has released about $59.0 \%$ of the carbon stock originally accumulated in the top surface layers of soil under native forest followed by open-bush land (58.0\%) and Eucalyptus plantation which has released about $51.8 \%$. Considering the soil depth within land uses, SOC stock was declined by $42.52 \%$ under soils in the open bush land followed by $39.43 \%$ reduction under soils in the natural and mixed forest. On the other hand, lower SOC stock variation was observed under Eucalyptus plantation; which was 29.14\% followed by cultivated land $(-33.42 \%)$.

\section{Conversion of natural and mixed forest to Eucalyptus plantation}

Conversion of natural and mixed forest to Eucalyptus plantation declined the SOC stock by $27.61 \%$. This could be due to initial clearing of vegetation that significantly reduced inputs to the soil. This finding is consistent with Guo and Gifford (2002) who stated that an average 13\% decline in SOC was calculated for the conversion of natural forests to plantations. Similarly, Wu and Cai (2006) and Chen et al. (2004) reported that the lower organic matter contents in soil under plantation forests than under natural forests. On the other hand, Sohngen and Brown (2006) also reported that the conversion of natural hardwood forests to pine plantations can actually emit more carbon from the system.

\section{Conversion of natural and mixed forest to open bush land}

Conversion of forest to open-bush land declined the SOC stock by $28.36 \%$. The SOC stock under natural and mixed forest land was higher than open-bush land most probably because of differences in management practices between the two land use systems. This finding agrees with Abera and Belachew (2011) who stated that the soils under forest sites were well protected, with little disturbance but that of open bush lands were poorly managed; heavily overgrazed, and mostly they were susceptible to surface erosion and water logging. In addition to this, cow dung is largely used as fuel source rather than enriching SOC of open bush land sites. In the same study, Jaramillo et al. (2003) reported the SOC decreased after conversion to pasture. The authors also stated that conversion of forest to pasture has been examined in a few studies including assessment of changes in total ecosystem pools of carbon and nitrogen, as well as separate above- and below-ground estimates. Overall, the transition from forest to pasture led to decreased ecosystem carbon by $25 \%$.

\section{Conversion of natural and mixed forest to cultivated land}

Conversion of natural and mixed forest to cultivated land declined the SOC stock by $36.12 \%$. This could be due to due to low amount of organic materials applied to the soil coupled by reduced physical protection of SOC as a result of intensive cultivation and increased oxidation of soil organic matter and complete removal of the biomass from the field and due to severe deforestation, steep relief condition, and excessive erosion hazards. This result is in conformity with the finding of many other authors (Gebrekidan and Negassa 2006) (Tilahun, G: Soil fertility status as influenced by different land uses in Maybar areas of South Wello Zone, North Ethiopia. Ethiopia: MSc Thesis, Haramaya University, unpublished) elsewhere. The soil carbon loss after conversion of forest lands to cultivated land is also similar to result reported by Guo and Gifford (2002) who observed that $-42 \%(34-50 \%)$ in consideration of 37 studies.

Generally, the variation and their difference in the soil properties within the soil depth between land use land covers as compared to natural and mixed forest in the watershed is described under Table 5 below.

On the other hand, the variation in soil physical and chemical properties across the soil depth in the watershed under natural and mixed forest, cultivated land, Eucalyptus plantation, and open- and bush land is described under Table 7 below.

\section{Conclusions}

Land use/land cover changes have influenced some of the soil properties of soils in the study area. The change in textural fractions in the four land uses is attributed to human influences like overgrazing accelerating soil erosion. There is also significant difference in the soil bulk density across the land uses considered in the study area. Land use/land cover type influences soil organic carbon in soils. Accordingly, cultivated land had lower amounts of organic carbon than other land use/land cover types, suggesting the need for sustainable cropping systems such as crop rotation, addition of organic matter, and crop residues to reverse the situation. The low carbon input from the agricultural crop could not compensate for the large mineralization of organic matter in cultivated fields. Variation of organic carbon among 
Table 7 Pearson correlation matrix for soil physiochemical properties $(0-20 \mathrm{~cm})$

\begin{tabular}{|c|c|c|c|c|c|c|c|}
\hline & Sand & Silt & Clay & Moisture content & Bulk density & $\mathrm{pH}$ & SOC concentration \\
\hline Sand & 1 & & & & & & \\
\hline Silt & $-0.49^{*}$ & 1 & & & & & \\
\hline Clay & $-0.87^{* *}$ & 0.01 & 1 & & & & \\
\hline Moisture Content & 0.18 & $-0.72^{* *}$ & 0.19 & 1 & & & \\
\hline Bulk Density & -0.39 & 0.45 & -0.19 & $-0.34^{* *}$ & 1 & & \\
\hline $\mathrm{pH}$ & -0.13 & 0.32 & -0.04 & -0.12 & -0.04 & 1 & \\
\hline SOC concentration & - & - & - & -0.10 & $-0.26^{* *}$ & 0.03 & 1 \\
\hline SOC Stock & 0.32 & -0.05 & -0.39 & $-0.20^{*}$ & -0.03 & 0.02 & $0.96^{* *}$ \\
\hline
\end{tabular}

* and ${ }^{*}$ correlation is significant at $p=0.05$ and $p=0.01$, respectively

different land use/land cover types were minimal on the lower soil layer as compared to the surface soil layer, implying that the surface soil layer was most affected by different management practices.

This study indicates that there is an urgent need to improve soil fertility by developing sustainable land use/cover practices to reduce the rate of soil erosion and to ensure long-term sustainability of the farming system, as a result national efforts are urgently needed to protect the remaining forests and to implement extension programs to ensure sustainable use of lands and conservation of forested areas. In general, land use/land cover change presents a more serious threat to carbon storage when coupled with a changing climate.

\section{Acknowledgements}

The first author would like to thank Sweden University of Agriculture (SLU) and the Swedish Energy Agency for financial support and also Wondo Genet College of Forestry and Natural Resources for provision soil laboratory utensils and WGECSF for devotion during my study period.

\section{Funding}

This study was supported by Sweden University of Agriculture (SLU) through grant funded by the Swedish Energy Agency.

\section{Authors' contributions}

All authors conducted a survey together during the study period. The corresponding author, WA wrote the manuscript, collected, and analyzed the data. FY and EK participated in the design of the study and examined the manuscript. All authors read and approved the final manuscript.

\section{Ethics approval and consent to participate}

Not applicable

\section{Consent for publication}

Not applicable

\section{Competing interests}

The authors declare that they have no competing interests.

\section{Publisher's Note}

Springer Nature remains neutral with regard to jurisdictional claims in published maps and institutional affiliations.

\section{Author details}

${ }^{1}$ Hawassa Environment and Forest Research Center (HEFRC), Hawassa, Ethiopia. ${ }^{2}$ Wondo Genet College of Forestry and Natural Resources (WGCF-NR), School of Forestry, Hawassa University, Hawassa, Ethiopia.
${ }^{3}$ Department of Soil and Environment, Sweden University of Agricultural Sciences (SLU), Uppsala, Sweden.

Received: 10 January 2018 Accepted: 9 July 2018

Published online: 07 August 2018

\section{References}

Abera, Y., \& Belachew, T. (2011). Effects of land use on soil carbon and nitrogen in soils of bale, southeastern Ethiopia. Tropical \& Sub Tropical Agro Ecosystems, 14(14), 229-235.

Alemayehu, L., Hager, H., \& Sieghardt, M. (2010). Effect of land use types on soil chemical properties in smallholder farmers of central highland Ethiopia. Ekologia (Bratislava), 29(1), 1-14.

Askin T and Ozdemir N, (2003). Soil bulk density as related to soil particle size distribution and organic matter content. Karadeniz Technical University, Faculty of Agriculture, Department of Soil Science, Turkey. ISSN 1330-7142.

Blake, G. R., \& Hartge, K. H. (1986). Bulk density. Chapter 13. Page 363-375. In A. Klute (Ed.), Methods of soil analysis: part 1 physical and mineralogical methods (2nd ed., p. 1188). Madison: American Society of Agronomy-Soil Society of America.

Bouyoucos, G. J. (1962). Hydrometer method improved for making particle size analysis of soil. Journal of American Society of Agronomy, 54, 464-465.

Carter, M. R. (Ed.). (1993). Soil sampling and methods of analysis. Boca Raton: Lewis Publishers.

Chen, C. R., Xu, Z. H., \& Mathers, N. J. (2004). Soil carbon pools in adjacent natural and plantation forests of subtropical Australia. Soil Science Society of America Journal, 68, 282-291.

Djukic, I., Zehetner, F., Tatzber, M., \& Gerzabek, M. H. (2010). Soil organic-matter stocks and characteristics along an alpine elevation gradient. Journal of Plant Nutrition and Soil Science, 173, 30-38.

Don, A., Schumacher, J., \& Freibauer, A. (2011). Impact of tropical land-use change on soil organic carbon stocks - a meta-analysis. Global Change Biology, 17, 1658-1670

Don, A., Schumacher, J., Scherer-Lorenzen, M., Scholten, T., \& Schulze, E. D. (2007) Spatial and vertical variation of soil carbon at two grassland sites_implications for measuring soil carbon stocks. Geoderma, 141, 272-282.

Egli, M., Sartori, G., Mirabella, A., Favilli, F., Giaccai, D., \& Delbos, E. (2009). Effect of north and south exposure on organic matter in high alpine soils. Geoderma, 149, 124-136.

Eshete A., Sterck F., \& Bongers F. (2011) Diversity and production of Ethiopian dry woodlands explained by climate- and soil-stress gradients. Forest Ecology and Management 261 (9):1499-1509.

Eshetu, Z., Giesler, R., \& Hogberg, P. (2004). Historical land use pattern affects the chemistry of forest soils in the Ethiopian highlands. Geoderma, 118, 149-165.

Fantaw, Y., \& Abdu, A. (2011). Soil property change following conversion of acacia woodland into grazing and farmlands in the Rift Valley Area of Ethiopia. Land Degradation and Development, 22, 425-431.

FAO. (2005). Global Forest resources assessment 2005: progress towards sustainable forest management. Rome: FAO.

Fermont, A. M., van Asten, P. J. A. ., \& Giller, K. E. (2008). Increasing land pressure in East Africa: the changing role of cassava and consequences for sustainability of farming systems. Agriculture, Ecosystems and Environment, $128,239-250$. 
Gebrehiwot, S. G., Bewket, W., Gardenas, A. I., \& Bishop, K. (2013). Forest cover change over four decades in the Blue Nile Basin, Ethiopia: comparison of three watersheds. Regional Environmental Change, 14, 253-266.

Gebrekidan, H., \& Negassa, W. (2006). Impact of land use and management practices on chemical properties of some soils of Bako area, western Ethiopia. Ethiopian Journal of Natural Resources, 8(2), 177-197.

Guo, L., \& Gifford, R. (2002). Soil carbon stocks and land use change. A metaanalysis. Global Change Biology, 8, 345-360.

Haileslassie, A., Priess, J., Veldkamp, E., Teketay, D., \& Lesschen, J. P. (2005). Assessment of soil nutrient depletion and its spatial variability on smallholders' mixed farming systems in Ethiopia using partial versus ful nutrient balances. Agriculture, Ecosystems and Environment, 108, 1-16.

Homann, P. S., Remillard, S. M., Harmon, M. E., \& Bormann, B. T. (2004). Carbon Storage in Coarse and Fine Fractions of Pacific Northwest Old-Growth Forest Soils. Soil Science Society of America Journal, 68, (6):2023.

Hooker, D. T., \& Stark, M. J. (2008). Soil carbon and nitrogen cycling in three semiarid vegetation types: response to an in situ pulse of plant detritus. Soil Biology and Biochemistry, 40, 2678-2685.

ICARDA. (2013). Methods of soil, plants, and water analysis: A manual for west Asia and North Africa regions. International Center for Agricultural Research in the Dry Areas (ICARDA), Beirut, Lebanon.

IPCC. (2007). Climate change impacts, adaptation and vulnerability, Contribution of Working Group II to the Fourth Assessment Report of the Intergovernmental Panel on Climate Change, M.L., Parry, O.F., Canziani, J.P., Palutikof, P.J., vander Linden and Hanson C.E., Eds. (p. 976). Cambridge: Cambridge University Press.

Islam, K.R., \& Weil, R.R. (2000). Land use effects on soil quality in a tropical forest ecosystem of Bangladesh. Agriculture, Ecosystems \& Environment, 79, (1):9-16.

Jaramillo, V. J., Kauffman, J. B., Rentería-Rodríguez, L., Cummings, D. L., \& Ellingson, L. J. (2003). Biomass, carbon, and nitrogen pools in Mexican tropical dry forest landscapes. Ecosystems, 6, 609-629.

Jaiyeoba, I. A. (1998). Changes in soil properties related to conversion of savannah woodland into pine and eucalyptus plantations, Northern Nigeria. Land Degradation \& Development, 9, (3):207-215.

Karaoz, O. (1989). Analyze methods of some chemical soil properties (pH, carbonates, salinity, organic matter, total nitrogen, and available phosphorus). Review of the Faculty of Forestry, University of Istanbul, 39(B3), 64-82 Istanbul, Turkish.

Kidanemariam, A., Gebrekidan, H., Mamo, T., \& Kibret, K. (2012). Impact of Altitude and Land Use Type on Some Physical and Chemical Properties of Acidic Soils in Tsegede Highlands, Northern Ethiopia. Open Journal of Soil Science, 02, 223-233. https://doi.org/10.4236/ojss.2012.23027.

Kidanu, S., \& Mamo, T. (2003). Land use changes and erosion on some highland soils of Ethiopia. Ethiopian Journal of Natural Resources, 5(2), 215-231.

Kizilkaya, R., \& Dengiz, O. (2010). Variation of land use and land cover effects on soil some physicochemical characteristics and soil enzyme activity. Zemdirbyste-Agriculture, 97, 15-24.

Korner, C. (2003). Alpine plant life: functional plant ecology of high mountain ecosystems (2nd ed.). Heidelberg: Springer Berlin.

Leifeld, J., Bassin, S., \& Fuhrer, J. (2005). Carbon stocks in Swiss agricultural soils predicted by land-use, soil characteristics, and altitude. Agriculture, Ecosystems and Environment, 105, 255-266.

Lemenih, M., Olsson, M., \& Karltun, E. (2004). Comparison of soil attributes under Cupressus Iusitanica and Eucalyptus saligna established on abandoned farmlands with continuously cropped farmlands and natural forest in Ethiopia. Forest Ecology and Management, 195, (1-2):57-67.

Lemma, B., Kleja, D. B., Nilsson, I., \& Olsson, M. (2006). Soil carbon sequestration under different exotic tree species in south-western highlands of Ethiopia. Geoderma, 136, 886-898.

Luyssaert, S., Schulze, E.-D., Borner, A., Knohl, A., Hessenmoller, D., Law, B. E., Ciais, P., \& Grace, J. (2008). Old-growth forests as global carbon sinks. Nature, 455, 213-215.

Murage, W. E., Karanja, K. N., Smithson, C. P., \& Woomer, L. P. (2000). Diagnostic indicators of soil quality in productive and non-productive smallholders' fields of Kenya's central highlands. Agriculture, Ecosystems and Environment, 79, 1-8.

Reicosky, D. C., \& Forcella, F. (1998). Cover crop and soil quality interactions in agro-ecosystems. Journal of Soil and Water Conservation, 53(3), 224-229.

Sanchez, F. G., Tiarks, A. E., Kranabetter, J. M., Page-Dumroese, D. S., Powers, R. F., Sanborn, P. T., \& Chapman, W. K. (2006). Effects of organic matter removal and soil compaction on fifth-year mineral soil carbon and nitrogen contents for sites across the United States and Canada. Canadian Journal of Forest Research, 36, 565-576.

SAS Institute, (2002). The SAS system for Microsoft Windows. Release 9.0, Cary, NC, USA.
Sasikumar, K., Vijayalakshmi, C., \& Parthiban, K.T. (2002). Alleopathic effects of Eucalyptus on blackgram (Phaseolus mungo L.). Allelopathy Journal, 9, 205-14.

Shisanya, C.A., Mucheru, M.W., Mugendi, D.N., \& Kung'u, J.B. (2009). Effect of organic and inorganic nutrient sources on soil mineral nitrogen and maize yields in central highlands of Kenya. Soil and Tillage Research, 103, 239-246.

Simo, I., Herrero, C., Boixadera, J., Poch, R.M., (2010). Accuracy of soil organic carbon inventories in Mediterranean mountain areas, world congress of soil science.

Singh, B. R. and Lal, R. 2001. The potential of Norwegian soils to sequester carbon through land use conversion and improved management practices. Ohio State University, USA.

Singh, P. (1995). Land degradation: A global menace and its improvement through Agroforestry. In: Singh, P. Pathak, P.S. and Roy, M.M. (eds). Agroforestry Systems for Sustainable Land Use. Science publishers, Inc. USA, 4-20.

Slaymaker, O., Spencer, T., Embleton-Hamann, C., (2009). Geomorphology and global environmental change, Cambridge University Press.

Sohngen, B., \& Brown, S. (2006). The influence of conversion of forest types on carbon sequestration and other ecosystem services in the South Central United States. Ecological Economics, 57, 698-708.

Takele, L., Chimdi, A., \& Mengistie, A. (2015). Impacts of Land use on Selected Physicochemical Properties of Soils of Gindeberet Area, Western Oromia, Ethiopia. Science, Technology and Arts Research Journal 3. 36. https://doi.org/ 10.4314/star.v3i4.5

Tan, B., Hu, J., Huang, D., Yang, W., Zhang, P., Shabanov, N.V., Knyazikhin, Y., Nemani, R.R., \& Myneni, R.B. (2005). Assessment of the broadleaf crops leaf area index product from the Terra MODIS instrument. Agricultural and Forest Meteorology, 135, (1-4):124-134.

Theurillat, J.-P., Felber, F., Geissler, P., Gobat, J.-M., Fierz, M., Fischlin, A., Küpfer, P., Schlüssel, A., Velluti, C., Zhao, G.-F., \& Williams, J. (1998). Sensitivity of plant and soil ecosystems of the Alps to climate change. In P. D. Cebon, U. Dalrinden, H. C. Davies, D. Imboden, \& C. C. Jaeger (Eds.), Views from the Alps. Regional perspectives on climate change. Massachusetts: MIT Press.

Trujilo, W., Amezquita, E., Fisher, M. J., \& Lal, R. (1997). Soil organic carbon dynamics and land use in the Colombian Savannas: aggregate size distribution. In R. Lal, M. Kimble, R. F. Follett, \& B. A. Stewart (Eds.), Soil processes and the carbon cycle (pp. 267-280). Boca Raton: CRC Press.

Van der Werf, G.R., Morton, D., Defries, R., Olivier, G.J.J., Kasibhatla, P.S., Jackson, R. B., Collatz, G.J., \& Randerson, J.T., (2009). CO2 emissions from forests. Nature Geoscience, 2. https://doi.org/10.1038/ngeo671.

Van Miegroet, H., Boettinger, J. L., Baker, M. A., Nielsen, J., Evans, D., \& Stum, A. (2005). Soil carbon distribution and quality in a montane rangeland-forest mosaic in northern Utah. Forest Ecology and Management, 220, 284-299.

Van Miegroet, H., Moore, P. T., Tewksbury, C. E., \& Nicholas, N. S. (2007). Carbon sources and sinks in high-elevation sprucer forests of the southeastern US. Forest Ecology and Management, 238, 249-260.

Vance, E. D. (2000). Agricultural site productivity: principles derived from longterm experiments and their implications for intensively managed forests. Forest Ecology and Management, 138, 369-396.

Walkley, A., \& Black, C. A. (1934). An examination of the Degtjareff method for determining soil organic matter and proposed modification of the chromic acid titration method. Soil Science, 37, 29-38.

Wild, A. (2003). Soils, land and food: managing the land during the twenty-first century. Cambridge University Press (p. 246).

Wu, L. Z., \& Cai, Z. C. (2006). The relationship between spatial scale and the variation of soil organic matter in China. Advances in Earth Science, 21, 965-971.

Yimer F., Ledin, S., \& Abdu, A. (2006). Soil property variations in relation to topographic aspect and vegetation community in the south-eastern highlands of Ethiopia. Forest Ecology and Management, 232, 90-99.

Yimer, F., Stig, L., \& Abdukadir, A. (2007). Changes in soil organic carbon and total nitrogen contents in three adjacent land use types in the Bale Mountains, south-eastern highlands of Ethiopia. Journal of Forest Ecology \& Management, 242(2-3), 337-342.

Yuksek, T., Ceyhun, G., Filiz, Y., \& Esin, E. Y. (2009). The effects of land use changes on soil properties: the conversion of Alder coppice to tea plantations in the humid northern Black Sea region. African Journal of Agricultural Research, 4(7), 665674.

Zhou, G., Liu, S., Li, Z., Zhang, D., Tang, X., Zhou, C., Yan, J., \& Mo, J. (2006). Oldgrowth forests can accumulate carbon in soils. Science, 314, 14-17. 